\title{
DOUBLE-BLIND TRIAL OF THE TREATMENT OF EPISCLERITIS-SCLERITIS WITH OXYPHENBUTAZONE OR PREDNISOLONE*
}

BY

\author{
P. G. WATSON, D. J. LOBASCHER, D. W. SABISTON, E. LEWIS-FANING, \\ P. D. FOWLER, AND B. R. JONES \\ Institute of Ophthalmology, University of London
}

THE clinical impression of one of us (D.W.S.) that oxyphenbutazone (Tanderil) had a markedly beneficial effect on episcleritis gained some confirmation by the short report of Bannerjee and Taylor (1961). It was therefore decided to carry out a controlled double-blind trial.

The object of this trial was to assess the comparative value of oxyphenbutazone as an alternative to prednisolone in the treatment of scleritis and episcleritis in patients in whom systemic treatment was indicated. In addition, it was hoped that some light could be shed on the diagnosis and aetiology of this group of diseases.

Inflammation of the episclera without involvement of the underlying sclera is termed episcleritis. Two types are generally recognized, simple episcleritis (including episcleritis periodica fugax) and nodular episcleritis (Fuchs, 1895; Schirmer, 1895; Duke-Elder, 1938). Simple episcleritis is a disease of young or middle-aged adults characterized by diffuse congestion, with or without oedema of the episclera, accompanied by local pain and headache. Simple episcleritis often recurs at regular intervals and there may be a family history of the complaint. Although there may be no visible residium after each attack, this type of episcleritis is said to progress after many attacks to a scleritis or sclerokeratitis (Duke-Elder, 1938).

Nodules can occur in the episclera in gout, tuberculosis, syphilis, zoster, and other conditions, including metastatic pyogenic infections. Most frequently, no aetiological factor can be found and the condition is then described as nodular episcleritis, a recurrent disease found especially in the middle-aged or elderly (Duke-Elder, 1938). It is characterized by the appearance in the episclera of nodules surrounded by haloes of injected episcleral vessels, and occasionally the overlying conjunctival vessels are injected. Nodular episcleritis is usually a benign condition which does not progress to scleritis. Scleritis may have nodules associated with it but this does not mean that the condition started as a nodular episcleritis (Swan, 1951).

Scleritis is a severe disease and can ultimately be blinding. It causes severe pain and headache; many eyes are removed for intractable pain. It is usually subdivided, according to the site involved, into sclerokeratitis, anterior and posterior scleritis. If the inflammation is very severe with pitting oedema of the overlying episclera, it is termed brawny scleritis. It is almost always accompanied by an anterior or posterior uveitis. It is most often associated with rheumatoid arthritis, polyarteritis nodosa, or Wegener's granulomatosis. Rheumatic nodules in the sclera

\footnotetext{
* Received for publication September 24, 1965.
} 
may rarely cause holes to appear in the sclera without the surrounding signs of inflammation. The condition is then known as scleromalacia perforans (van der Hoeve, 1934). In this trial, scleritis was divided into mild, moderate, or severe, regardless of position or particular manifestation.

Before the introduction of steroids the treatment of episcleritis and scleritis was regarded as difficult and unrewarding. There is almost universal agreement on the value of local steroids in the suppression of the inflammation in episcleritis, particularly during the first attack, but the situation is far less satisfactory in recurrent episcleritis and in scleritis where the disease often progresses in spite of local therapy.

\section{Organization of the Trial}

The difficulty of assessing the prognosis in episcleritis led us to include all cases referred in which the condition had deteriorated or recurred in spite of previous local steroid therapy. It was reasonable, therefore, to use drugs which were known to have occasional unpleasant side-effects.

The two groups of patients, the oxyphenbutazone-treated group (Group O) and the prednisolone-treated group (Group P) were balanced on entry to the trial by the method of stratified randomization according to age, length of history, and severity of disease. Two age groups (under 45 years and 45 years and over), two length-of-history groups (under one month, one month and over), and three severity groups (simple episcleritis, nodular episcleritis, and scleritis) were used, giving twelve possible sub-groups. Previous treatment was disregarded, except that patients who had had subconjunctival injections of steroids, or systemic steroids, pyrazoles, or aspirin (over gr. 30 a day) during the past 3 months, were excluded. Patients with contraindications to either drug were, of course, excluded. Local steroids were not used during the trial.

\section{Assessment of Severity of Disease and Response to Treatment}

The following factors were noted when the patients entered the trial:

(1) Pain; (2) flare; (3) keratic precipitates; (4) cells; (5) episcleral injection; (6) conjunctival injection; (7) keratitis (type); (8) keratitis (degree); (9) scleral thinning; (10) nodules.

Table I (opposite) summarizes the factors considered in assessing the original category and the response to treatment. The trial was planned to last 56 days; the patients were seen weekly for 4 weeks and then fortnightly.

\section{Treatment}

Tablets of prednisolone $5 \mathrm{mg}$. were manufactured to match exactly tablets of oxyphenbutazone $100 \mathrm{mg}$. In each group the dosage scheme was as given in Table II (opposite).

At the beginning of treatment each patient was given a bottle which contained enough tablets to last the duration of the treatment, and the selection of treatmentoxyphenbutazone or prednisolone-was arranged by use of random number tables. The observation was a double-blind throughout; the key was held by the pharmacist and referred to only in cases of emergency. At the outset it was hoped to include sixty patients in the trial

This dosage was selected because it had been found in a preliminary study to give adequate suppressive response. 
TABLE I

Symptoms and Signs and the Numerical Values assigned to their Severity*

\begin{tabular}{|c|c|c|c|c|c|}
\hline $\begin{array}{c}\text { Symptoms and } \\
\text { Signs }\end{array}$ & 0 & 1 & 2 & 3 & 4 \\
\hline (1) Pain & Absent & Mild; intermittent & $\begin{array}{l}\text { Moderate inter- } \\
\text { mittent, or mild } \\
\text { constant }\end{array}$ & $\begin{array}{l}\text { Severe intermittent, } \\
\text { or moderate } \\
\text { constant }\end{array}$ & $\begin{array}{l}\text { Severe; } \\
\text { constant }\end{array}$ \\
\hline (2) Flare & Absent & Mild & Moderate & Severe & $\begin{array}{c}\text { Severe } \\
+ \text { exudate }\end{array}$ \\
\hline $\begin{array}{l}\text { (3) Keratic } \\
\text { precipitates }\end{array}$ & Absent & Minimum & Moderate & Heavy "carpet" & $\begin{array}{l}\text { Confluent or } \\
\text { mutton-fat }\end{array}$ \\
\hline (4) Cells & Absent & Few & Moderate & Marked & - \\
\hline $\begin{array}{l}\text { (5) Episcleral } \\
\text { injection }\end{array}$ & Absent & $\begin{array}{l}\text { One quadrant } \\
\text { affected }\end{array}$ & $\begin{array}{l}\text { Two quadrants } \\
\text { affected }\end{array}$ & $\begin{array}{c}\text { Three quadrants } \\
\text { affected }\end{array}$ & $\begin{array}{l}\text { Four quadrants } \\
\text { affected }\end{array}$ \\
\hline $\begin{array}{l}\text { (6) Conjunctival } \\
\text { injection }\end{array}$ & Absent & $\begin{array}{l}\text { One quadrant } \\
\text { affected }\end{array}$ & $\begin{array}{l}\text { Two quadrants } \\
\text { affected }\end{array}$ & $\begin{array}{l}\text { Three quadrants } \\
\text { affected }\end{array}$ & $\begin{array}{l}\text { Four quadrants } \\
\text { affected }\end{array}$ \\
\hline $\begin{array}{l}\text { (7) Keratitis } \\
\text { (degree) }\end{array}$ & Absent & $\begin{array}{l}\text { One quadrant } \\
\text { affected }\end{array}$ & $\begin{array}{l}\text { Two quadrants } \\
\text { affected }\end{array}$ & $\begin{array}{c}\text { Three quadrants } \\
\text { affected }\end{array}$ & $\begin{array}{c}\text { Four quadrants } \\
\text { affected }\end{array}$ \\
\hline $\begin{array}{l}\text { (8) Keratitis } \\
\text { (type) }\end{array}$ & Absent & $\begin{array}{l}\text { Epithelial } \\
\text { keratitis }\end{array}$ & $\begin{array}{c}\text { Superficial } \\
\text { vascularization }\end{array}$ & $\begin{array}{c}\text { Marginal } \\
\text { infiltration }\end{array}$ & $\begin{array}{c}\text { Gutter-like } \\
\text { ulcers at limbus }\end{array}$ \\
\hline $\begin{array}{l}\text { (9) Scleral } \\
\text { thinning }\end{array}$ & Absent & $\begin{array}{l}\text { One quadrant } \\
\text { affected }\end{array}$ & $\begin{array}{c}\text { Two quadrants } \\
\text { affected }\end{array}$ & $\begin{array}{c}\text { Three quadrants } \\
\text { affected }\end{array}$ & $\begin{array}{l}\text { Four quadrants } \\
\text { affected }\end{array}$ \\
\hline
\end{tabular}

* Each of the indices listed above was graded on a 5-point scale, 0 to 4, except cells, 0 to 3 points.

In addition, the nodules (10) were categorized and scored as follows: Just definite 1; fairly obvious 2; very obvious 6; large confluent 10.

TABLE II

DaIly Dosages (mg.)

\begin{tabular}{l|c|c}
\hline \multicolumn{1}{c|}{ Schedule } & \multicolumn{2}{|c}{ Drug (mg.) } \\
\cline { 2 - 3 } & Oxyphenbutazone & Prednisolone \\
\hline For 2 days-2 tablets 3 times a day & 600 & 30 \\
For a total of 3 weeks-1 tablet 4 times a day & 400 & 20 \\
Then a tail-off for one week: & 300 & 15 \\
For 2 days-1 tablet 3 times a day & 200 & 10 \\
For 2 days-1 tablet twice daily & 100 & 5 \\
For 3 days-1 tablet daily & & \\
\hline
\end{tabular}

\section{Aetiology}

In an attempt to find a common aetiological factor, a full blood count, erythrocyte sedimentation rate, Waaler-Rose or latex agglutination test, Wassermann reaction, Kahn test, and serum uric acid estimations were carried out. The abnormalities discovered are summarized in Table III (overleaf).

The denominator shows the number of patients in whom the test was done and the numerator the number of positive results. 
TABLE III

RESULTS OF LABORATORY INVESTIGATIONS

\begin{tabular}{cc|c|c|c|c}
\hline \multicolumn{1}{c|}{ Treatment } & $\begin{array}{c}\text { Raised } \\
\text { E.S.R. }\end{array}$ & $\begin{array}{c}\text { + W.R. } \\
+ \text { Kahn }\end{array}$ & $\begin{array}{c}\text { + Latex } \\
+ \text { Waaler-Rose } \\
\text { or Both }\end{array}$ & $\begin{array}{c}\text { Raised } \\
\text { Serum } \\
\text { Uric Acid }\end{array}$ \\
\hline $\begin{array}{l}\text { Oxyphenbutazone } \\
\text { Prednisolone }\end{array}$ & (O) & $16 / 29$ & $2 / 19$ & $3 / 18$ & $6 / 21$ \\
\hline
\end{tabular}

The normal ranges used for the above results are as follows:

Erythrocyte sedimentation rate
Serum uric acid: upper limits of normal $\begin{cases}\text { Males } & 1-10 \mathrm{~mm} . / \mathrm{hr} . \\ \text { Females } & 1-20 \mathrm{~mm} . / \mathrm{hr} . \\ \text { Males } & 6 \mathrm{mg} . / 100 \mathrm{ml} . \\ \text { Females } & 5 \mathrm{mg} . / 100 \mathrm{ml} .\end{cases}$

It is interesting that four out of the first five patients in the trial had very high serum uric acid levels. Unfortunately, the test was not repeated in those cases where a raised level was found. The interpretation of this test is difficult because it is now appreciated that there can be considerable variation in results (Bywaters and Holloway, 1964). There was no overt clinical evidence of gout in any of these cases.

The three with positive tests for syphilis were referred to the special department, but continued in the trial; one was later found to have false positives.

Of the patients with positive latex or Waaler-Rose tests, only two had associated systemic disease: one Henoch-Schönlein purpura and one rheumatoid arthritis.

\section{Results of the Trial}

\section{Assessment of the Similarity of the Two Treatment Groups at the Start of the Trial}

Entry to the trial ceased when the sixtieth person had been admitted, but one was later excluded because of doubtful diagnosis, leaving 30 persons who were given oxyphenbutazone and 29 given prednisolone. Detailed statistical examination of the data on sex, age, severity, and duration of the disease was made. This showed the two groups to be similar, regardless of whether the figures were based on persons or eyes affected. Though the oxyphenbutazone group had a female preponderance (63 per cent. to 55 per cent.) this was not statistically significant (throughout this report, statistical significance is that $P<0.05$ ). The mean age of the oxyphenbutazone group was $46.9 \pm 2.52$ years, and that of the prednisolone group $47.3 \pm$ $2 \cdot 61$ years, and the distributions were similar.

The three diagnostic categories were present in similar proportions in both treatment groups, except that there were three patients with scleritis in the oxyphenbutazone group and only one in the prednisolone group, the latter being later excluded from analysis because of non-attendance, suggesting that the oxyphenbutazone group was slightly more severely affected.

Both eyes were affected at some period of the trial in five patients of the oxyphenbutazone group, and ten of the prednisolone group. In making the clinical assessments for these patients, each eye was graded separately and the analysis which follows is based on the number of eyes rather than on the number of persons affected. 
Thus, the oxyphenbutazone group comprised 35 eyes and the prednisolone group 39 eyes, rather than 30 and 29 persons respectively. This did not materially alter the sex and age distributions, nor was the difference in the distribution of length of history affected.

\section{Initial Assessment}

The signs and symptoms recorded at the first and subsequent assessments (Days $0,7,14,21,28,42$, and 56) are shown in Table I. As already indicated, arrangements were made for the two treatment groups to be balanced for the factors of age, severity of disease, and length of history. Before comparing the results in the two groups it was important to show that they were similar in respect of the presenting symptoms and signs. Four main points emerged:

(1) As the majority of the eyes did not have any flare, keratic precipitates, cells, keratitis, or scleral thinning, there was little room for improvement on either drug.

(2) The distribution of the pain in the two groups was significantly dissimilar. In 45 per cent. of the oxyphenbutazone group it was either absent or only mild and intermittent, as against 38 per cent. of the prednisolone group.

(3) On the small numbers involved it was not possible to demonstrate significant differences as regards episcleral and conjunctival injection, but the precentages suggest that the two groups could hardly be termed alike as regards these characteristics (e.g. episcleral injection was present in 100 per cent. of the oxyphenbutazone group and in 89 per cent. of the prednisolone group).

(4) The mean nodule scores at the start of the trial were $3.52 \pm 0.58$ for the oxyphenbutazone group and $3.24 \pm 0.55$ for the prednisolone group-very similar.

\section{Patients withdrawn from the Trial}

Patients who, for any reason, were not assessed up to the 56th day of the trial were regarded as withdrawals. An occasional failure to attend for assessment on any day but the 56th was ignored in analysing the data, the grades on such single days of the non-attendance being regarded as unchanged from the previous assessment.

Eight patients from the oxyphenbutazone group (all with only one eye affected) and seven from the prednisolone group (one with both eyes affected) were withdrawn. The reasons for withdrawal, including breaking the code because of failure to respond to treatment, are summarized in Table IV.

TABLE IV

Reasons for WithdraWal of Patients from Trial

\begin{tabular}{c|c|c|c|c|c}
\hline \multirow{2}{*}{ Group } & \multicolumn{5}{|c}{ Withdrawal because of } \\
\cline { 2 - 6 } & $\begin{array}{c}\text { Failure of } \\
\text { Treatment }\end{array}$ & $\begin{array}{c}\text { Side-effects } \\
\text { due to Drug }\end{array}$ & $\begin{array}{c}\text { Apparent } \\
\text { Cure }\end{array}$ & $\begin{array}{c}\text { Inter-current } \\
\text { Illness }\end{array}$ & $\begin{array}{c}\text { Failure to } \\
\text { attend for } \\
\text { No Apparent } \\
\text { Reason }\end{array}$ \\
\hline O & 1 & 1 & 4 & 1 & 1 \\
\hline$P$ & 3 & 1 & 1 & $1^{*}$ & 1 \\
\hline
\end{tabular}

* Pulmonary tuberculosis diagnosed after 28 days' treatment. 


\section{Side-effects of Treatment noted during the Trial}

Table $\mathrm{V}$ shows the side-effects suffered by the patients and the abnormalities which were observed during the course of the trial. The effects which we believe to be either related or unrelated to the drug treatment are tabulated separately and the results based on our own experience and reports of other observers. Our conclusions

TABLE V

SidE-EFFECTS RELATED, OR NOT RELATED, TO THE DRUGS

\begin{tabular}{|c|c|c|c|c|}
\hline Side-Effects & $\begin{array}{l}\text { Case } \\
\text { No. }\end{array}$ & Reaction & Comment & $\begin{array}{l}\text { Due to } \\
\text { Drug }\end{array}$ \\
\hline \multirow{6}{*}{$\begin{array}{l}\text { Due, or } \\
\text { apparently due, to } \\
\text { Oxyphenbutazone }\end{array}$} & 56 & Lassitude, vomiting, and nausea & & Yes \\
\hline & 45 & $\begin{array}{l}\text { Day } 7 \text {-nausea; day } 14 \text {-neck } \\
\text { glands swollen; day } 21-\text { dryness } \\
\text { of mouth }\end{array}$ & & Yes \\
\hline & 18 & $\begin{array}{l}\text { Parotid and submaxillary gland } \\
\text { enlargement }\end{array}$ & $\begin{array}{l}\text { A known but infrequently re- } \\
\text { ported effect of oxyphenbutazone }\end{array}$ & Yes \\
\hline & 25 & Dyspnoea & $\begin{array}{l}\text { History of rheumatic fever, } \\
\text { tuberculosis, and deep X-ray } \\
\text { therapy after hysterectomy. Salt } \\
\text { retention probably played some } \\
\text { part in development of dyspnoea }\end{array}$ & Yes \\
\hline & 44 & $\begin{array}{l}\text { Infected throat. Dizzy, unsteady } \\
\text { at day } 7 \text {, still giddy at day } 14, \\
\text { when treatment stopped }\end{array}$ & $\begin{array}{l}\text { Symptoms cleared when treat- } \\
\text { ment stopped }\end{array}$ & Yes \\
\hline & 19 & Rash & $\begin{array}{l}\text { Flare-up of long-standing } \\
\text { eczema during treatment }\end{array}$ & $?$ \\
\hline \multirow{4}{*}{$\begin{array}{l}\text { Symptoms and } \\
\text { Signs probably } \\
\text { not related to } \\
\text { Treatment }\end{array}$} & 50 & Day 7-irritable, sluggish & $\begin{array}{l}\text { Treatment stopped for one day, } \\
\text { no return of symptoms }\end{array}$ & No \\
\hline & 42 & $\begin{array}{l}\text { Rash on face and eyelids; had } \\
\text { previously had atropine drops }\end{array}$ & $\begin{array}{l}\text { Rash cleared despite continua- } \\
\text { tion of tablets }\end{array}$ & No \\
\hline & 42 & Corneal ulcer & Part of eye disease & No \\
\hline & 47 & Corneal infiltration & Part of eye disease & No \\
\hline \multirow{7}{*}{$\begin{array}{l}\text { Due, or } \\
\text { apparently due, } \\
\text { to Prednisolone }\end{array}$} & 3 & $\begin{array}{l}\text { Day } 21-\text { severe indigestion and } \\
\text { dry mouth }\end{array}$ & - & Yes \\
\hline & 46 & Day 14-"terrible indigestion" & - & Yes \\
\hline & 53 & $\begin{array}{l}\text { Day 21-indigestion and leg } \\
\text { cramps }\end{array}$ & - & Yes \\
\hline & 24 & Day 7-glossitis & - & Yes \\
\hline & 34 & $\begin{array}{l}\text { Day 7-restlessness, sweating, } \\
\text { dyspepsia, constipation }\end{array}$ & - & Yes \\
\hline & 35 & $\begin{array}{l}\text { Day } 21 \text {-puffiness of head, face, } \\
\text { and neck. Clear on stopping } \\
\text { tablets }\end{array}$ & - & Yes \\
\hline & 12 & $\begin{array}{l}\text { Petechial haemorrhage in the } \\
\text { skin }\end{array}$ & $\begin{array}{l}\text { Long-standing Henoch-Schön- } \\
\text { lein purpura }\end{array}$ & No \\
\hline
\end{tabular}

Total number of patients with side-effects certainly due to oxyphenbutazone $=5$ and to prednisolone $=6$. 
are that there were five patients in Group $\mathrm{O}$ and six in Group $\mathrm{P}$ with side effects due to the drug, of which, as seen from the previous section, one in the oxyphenbutazone group and one in the prednisolone group were withdrawn from the trial. It is obvious from this Table that the difference in the number of side-effects is very slight. However, the types of side-effect in each group are quite dissimilar, apart from gastric symptoms.

\section{Comparison of the Two Methods of Treatment}

Pain

Resolution of Pain.-The number of eyes free from pain is shown graphically in Fig. 1. It can be seen that there is little difference between the two groups; the initial advantage in the prednisolone group was maintained for 21 days, but after this the oxyphenbutazone group had less pain.

Improvement in Pain.-The above method ignores improvement or deterioration. The graphs in Fig. 2 ( $a$ and $b$ ) show this as a percentage of eyes improving or deteriorating as compared with the previous assessment. There is very little difference in improvement rates (Fig. 2a), though a marked deterioration is shown in the prednisolone group between days 21 and 42 (Fig. $2 b$ ).

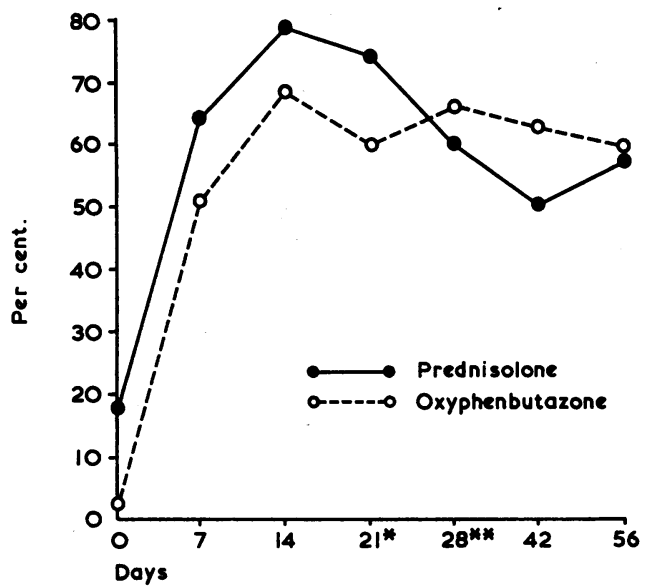

FIG. 1.-Resolution of pain, shown as percentage of eyes free from pain.

Key to All Diagrams

* Dosage reduction

** End of course of therapy

$\mathrm{S}=$ Statistically significant difference

FIG. 2.-(a) Pain improvement

(b) Pain deterioration (Overall percentages).

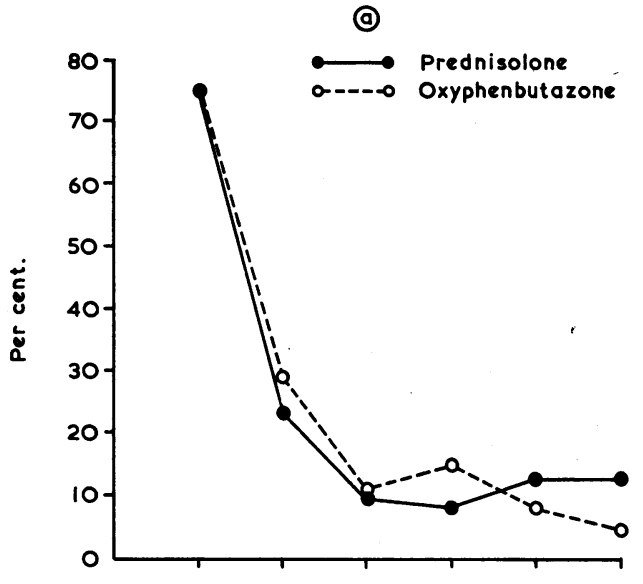

(b)

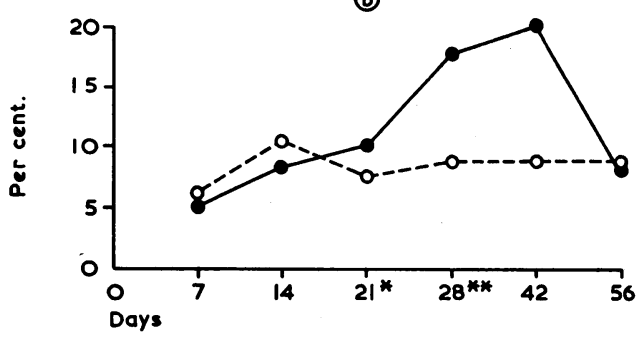


Improvement in Pain related to Possible Improvement.-At the onset of the trial the various grades were not similarly represented in the two treatment groups because more eyes were painless in the prednisolone group. Direct comparison of distribution of the various categories as the trial progressed was therefore not feasible.

It is obvious that when an eye is pain-free it cannot improve in this respect.

()

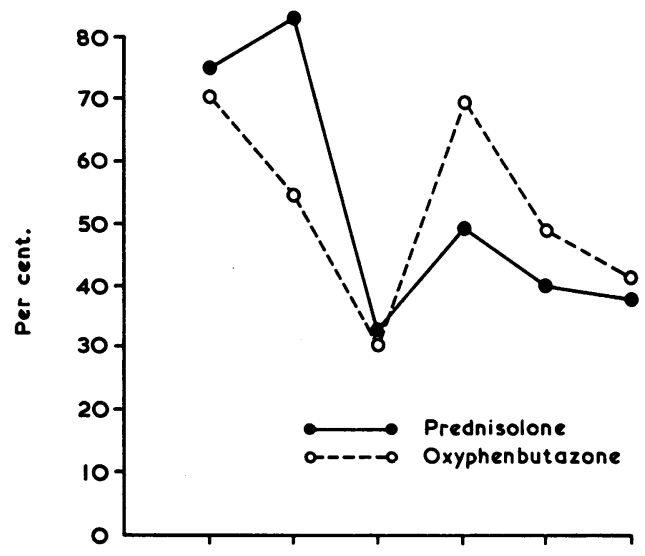

(b)

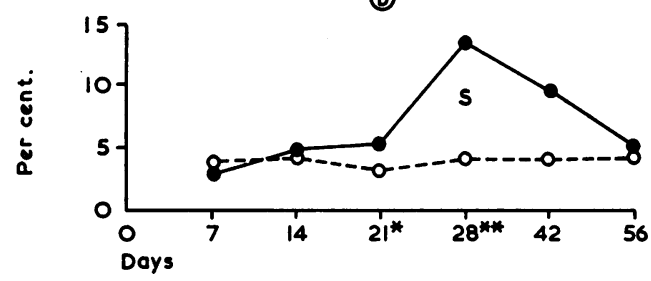

Fig. 3.- (a) Pain improvement

(b) Pain deterioration (Actual as a percentage of possible change).
Similarly, an eye giving severe and constant pain can improve much more than one with only slight and occasional pain. The possible degree of improvement on each assessment day was therefore calculated, i.e. each eye was graded numerically, showing how many grades it could improve. The total percentage improvement in each group was compared with that which was possible. Similarly, an eye giving severe and constant pain could not become more painful, whereas an eye with little pain could get much worse. Similar calculations were therefore made for deterioration in relation to possible deterioration.

The results of these calculations are shown in Fig. 3. Fig. 3b shows a statistically significant increase in pain in the prednisolone group between Days 21 and 28, a trend which continued to Day 42.

Improvement in Pain during the First 7 Days.-Detailed studies showed that while there was little difference between the numbers in the two groups who improved two or three grades, 81 per cent. of the oxyphenbutazone group improved one grade or more and 93 per cent. of the prednisolone group improved one grade or more, and this difference was statistically significant.

\section{Episcleral Injection}

Resolution of Episcleral Injection.-The percentage of eyes with no episcleral injection is shown in Fig. 4 (opposite). The groups improved in parallel for 2 weeks. In the third week the prednisolone group improved markedly and then deteriorated rapidly, while the oxyphenbutazone group showed maintenance or steady improvement from the third week onwards. 


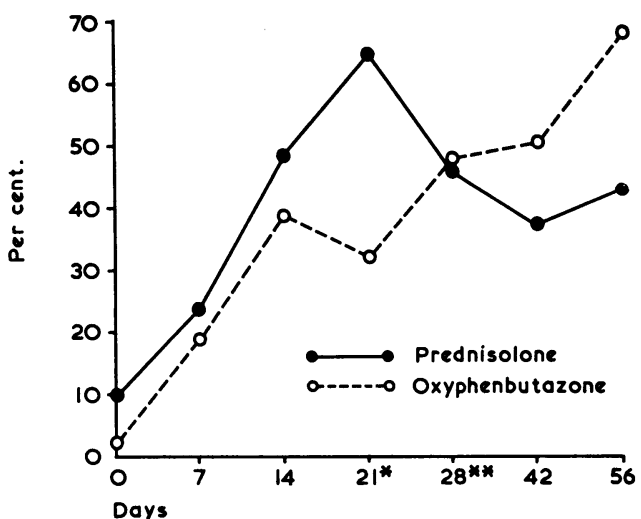

FIG. 4.-Resolution of episcleral injection, shown as percentage of eyes with no injection.

FIG. 5.-(a) Episcleral injection improvement

(b) Episcleral injection deterioration (Actual as a percentage of possible change).

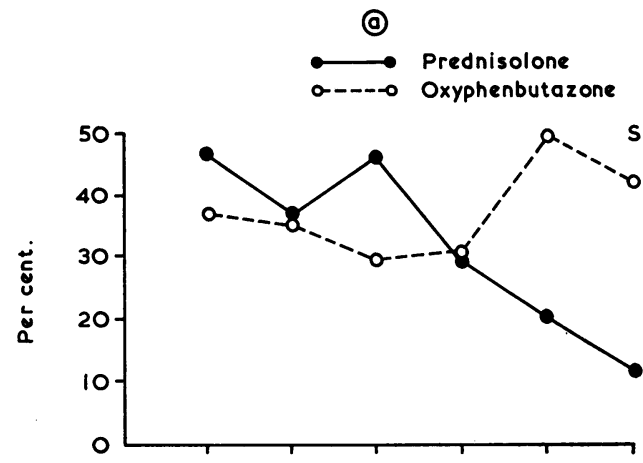

(b)

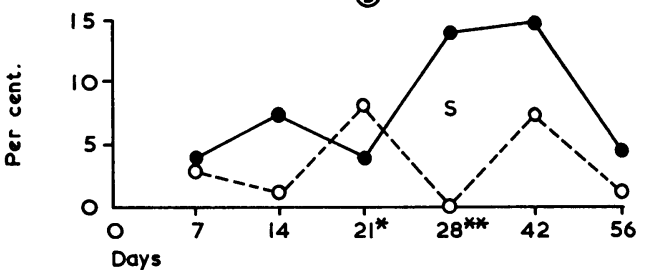

Improvement in Episcleral Injection in Relation to Possible Improvement.-This was studied in the same way as pain improvement, and is illustrated in Figs 5 (a and b).

These show similar trends, with improvement a little in favour of the prednisolone group in the third week, but marked statistically significant improvement in the oxyphenbutazone group in the last weeks of the trial when compared with the prednisolone group (Fig. 5a).

The deterioration in the steroid group was marked during the fourth week of the trial and significantly greater than that in the oxyphenbutazone group (Fig. 5b).

\section{Conjunctival Injection}

Resolution of Conjunctival Injection.-This is illustrated in Fig. 6 (overleaf). In the first week the oxyphenbutazone group did slightly better and during the second and third weeks the prednisolone group improved more, but after this the differences were slight.

Improvement in Conjunctival Injection in relation to Possible Improvement.-During the third week the greater improvement in the prednisolone group was statistically significant but there was marked deterioration in this group between the fourth and sixth weeks, these differences also being statistically significant (Figs 7a and b, overleaf).

Improvement in Conjuctival Injection during the First 7 days. - Of the oxyphenbutazone group 50 per cent. and of the prednisolone group 75 per cent. improved one or more grades during the first 7 days. This difference is significant and confirms the advantage of prednisolone during the early period of the trial. 


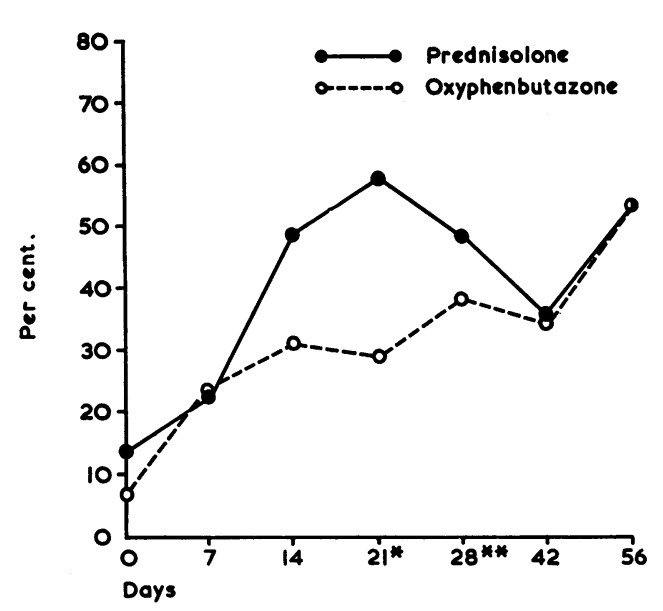

FIG. 6.-Resolution of conjunctival injection, shown as a percentage of eyes with no quadrants affected.

FIG. 7.-(a) Conjunctival injection improvement (b) Conjunctival injection deterioration (Actual as a percentage of possible change).

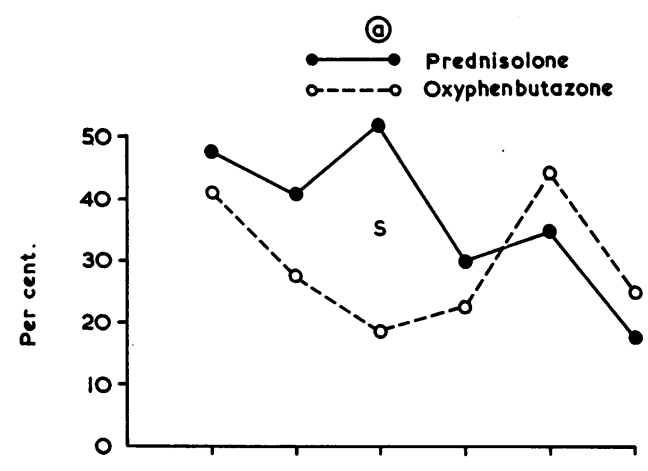

(b)

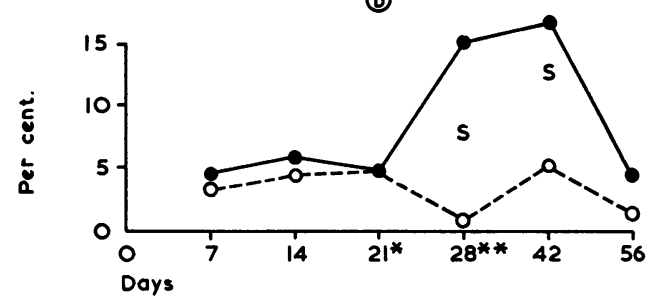

Flare, Keratic Precipitates, and Cells

These were present on too few occasions for conclusions to be drawn.

\section{Nodules}

Nodules were graded numerically, depending on size and number, and the total for each group was calculated for each assessment day.

Fig. 8 shows the mean score for nodules at each assessment day as a percentage of the score on Day 0 . The graph shows the more marked regression of nodules during the first 7 days in the prednisolone group, but the slower effect of the oxyphenbutazone was more complete and persisted, while the prednisolone group retrogressed during the last weeks of the trial. The differences between the two groups during the last weeks of the trial are statistically significant.

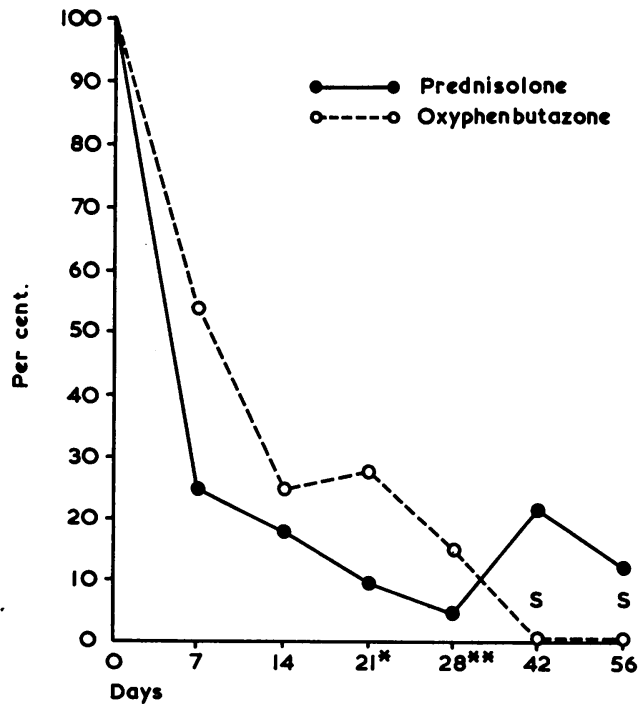

Fig. 8.-Nodules (Mean scores as a percentage of the scores at Day 0$)$. 


\section{Combined Scores for all Symptoms and Signs except Nodules}

All symptoms and signs (except scleral thinning and the quality of the keratitis) were given a numerical code and the means for each assessment day calculated. The results are shown graphically in Fig. 9. The groups can be seen to be very similar for 3 weeks, when the prednisolone group began to deteriorate while the oxyphenbutazone group continued to improve. The differences were statistically significant at Days 42 and 56.

\section{Total Scores for all Symptoms and Signs, including Nodules}

Fig. 10, which is very similar to Fig. 9, shows the steady improvement in both groups for 3 weeks, and thereafter the deterioration in the prednisolone group with continued improvement in the oxyphenbutazone group, producing statistically significant differences at Days 42 and 56.

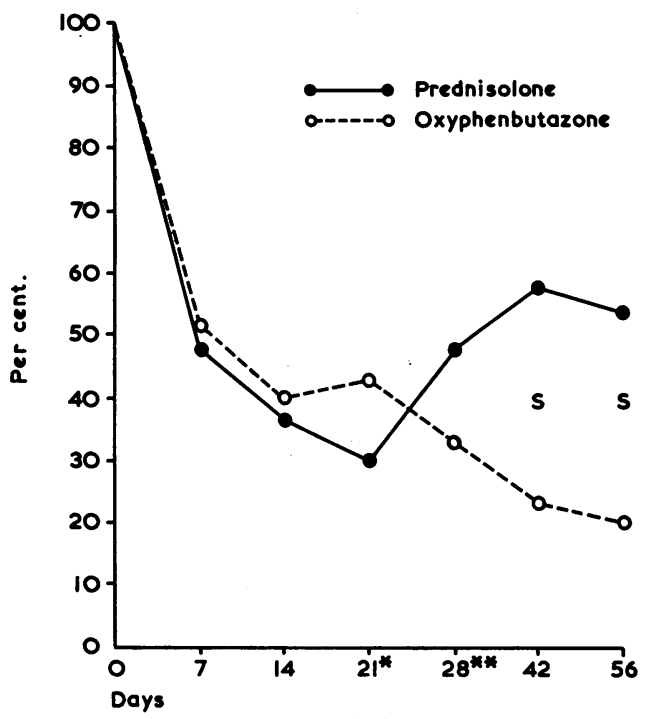

FIG. 9.-All symptoms and signs except nodules (Mean scores as a percentage of the score at Day 0).

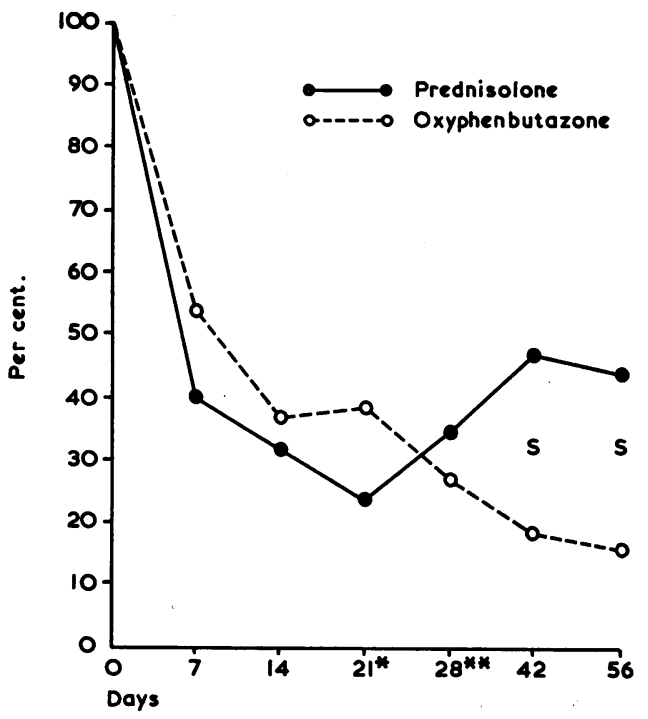

Fig. 10.-All symptoms, signs, and nodules (Mean scores as a percentage of the scores at Day 0).

\section{Discussion}

The initial assessment shows that the two groups were comparable in that they were similar as regards sex, age, general severity; and length of history, but not precisely alike as regards the severity of individual symptoms. Allowance has been made for these minor differences by the method adopted for comparing subsequent progress.

Analysis shows that the improvement in the two treatment groups was roughly parallel until Day 21. Some symptoms showed greater improvement on prednisolone, but not to a statistically significant degree except for conjunctival injection during the third week. After Day 21 the oxyphenbutazone group continued to improve rapidly in regard to pain, episcleral injection, and conjunctival injection, but the prednisolone group deteriorated after Day 21, particularly between Days 28 and 42 . Some symptoms, therefore, in the oxyphenbutazone group improved to a significantly greater extent than in the prednisolone group during the last month of the trial. 
As described on p. 468 , there was no marked difference in the occurrence of sideeffects between the two groups. This was to a certain extent due to the fact that patients with contraindications to the drugs were excluded. There were no sideeffects noted which had not previously been reported and none of really serious significance. From this it may be concluded that neither preparation had any marked advantage in this respect during the investigation.

A fixed-dosage double-blind trial of this nature always suffers in that it is difficult to know whether the drugs are being used to their best advantage. In this instance, it is possible, on the one hand, that the steroids may have been withdrawn too soon or too rapidly; on the other hand, it is possible that steroid-dependence may have been avoided by this short period of administration. Oxyphenbutazone has a halflife of about 3 days, but this cannot explain the differences, shown between the two groups. By extension of the trial we hope to obtain answers to these questions.

As episcleritis has a marked tendency to recur and, perhaps in some cases, to progress to scleritis, a long-term follow-up has been arranged to show whether the apparent sustained improvement of those patients given oxyphenbutazone continued over a long period.

\section{Summary}

(1) A double-blind controlled study was made into the effects of treatment of 59 patients with oxyphenbutazone (Tanderil) and prednisolone in episcleritis and scleritis. Oxyphenbutazone has been shown to be effective in the treatment of episcleritis. Too few cases of scleritis were studied to allow firm conclusions to be drawn.

(2) Oxyphenbutazone (600 mg./day) had less effect than prednisolone (30 mg./day) during the initial stages, but 3 weeks' treatment with oxyphenbutazone ( $400 \mathrm{mg}$./day) had a very similar effect to 3 weeks of prednisolone $(20 \mathrm{mg}$./day). With oxyphenbutazone the improvement produced was maintained, whereas the patients receiving prednisolone tended to deteriorate as treatment was withdrawn.

(3) No single aetiological factor was present in all the cases studied in this trial. The commonest associated condition was active rheumatic disease.

(4) Two patients receiving oxyphenbutazone and one patient receiving prednisolone were withdrawn from the trial because of side-effects attributable to the drugs.

We acknowledge our gratitude to the surgeons and staff of Moorfields Eye Hospital, for referring cases to Prof. Norman Ashton and the staff of the Department of Pathology of the Institute of Ophthalmology, for co-operation with diagnostic tests; to Mr. A. Baker, chief pharmacist of Moorfields Eye Hospital, for his co-operation; to Messrs. Pfizer Ltd. for the supply of prednisolone; to Geigy (U.K.) Ltd. for the supply of Tanderil.

\section{REFERENCES}

Anderson, B., and Margolis, G. (1952). Amer. J. Ophthal., 35, 917.

BANNERJEe, S. K., and TAYlOR, P. (1961). Trans. ophthal. Soc. U.K., 81, 651.

Bywaters, E. G. L., and Holloway, V. P. (1964). Ann. rheum. Dis., 23, 236.

Duke-Elder, S. (1938). "Text Book of Ophthalmology", vol. 2, pp. 2051-54. Kimpton, London.

- (1951). Brit. J. Ophthal., 35, 637. and GoldSMITH, A. J. B. (1951). Ibid., 35, 672.

FuCHS, E. (1895). v. Graefes Arch. Ophthal., 41, pt. 4, p. 229.

SCHIRMER, O. (1895). Ibid., 41, pt. 4, p. 158.

SWan, K. C. (1951). Arch. Ophthal. (Chicago), 45, 630.

VAN DER HOEVE, J. (1934). Ibid., 11, 111.

WERnER, L. E. J. (1960). Brit. J. Ophthal., 44, 755. 


\section{APPENDIX \\ DETAILS OF RESULTS}

\section{Comparison of Progress in the Two Treatment Groups}

Pain.-The distribution of the various degrees of pain at the onset of the trial is given in Table VI.

TABLE Vl

Percentage of Degrees of Pain

\begin{tabular}{l|c|c|c|c|c}
\hline \multicolumn{1}{c|}{ Group } & $\begin{array}{c}\text { Pain } \\
\text { absent }\end{array}$ & $\begin{array}{c}\text { Mild } \\
\text { intermittent }\end{array}$ & $\begin{array}{c}\text { Moderate } \\
\text { intermittent } \\
\text { or mild } \\
\text { constant }\end{array}$ & $\begin{array}{c}\text { Severe } \\
\text { intermittent } \\
\text { or moderate } \\
\text { constant }\end{array}$ & $\begin{array}{c}\text { Severe } \\
\text { constant }\end{array}$ \\
\hline $\begin{array}{l}\text { Oxyphenbutazone } \\
\text { Prednisolone }\end{array}$ & 6 & 39 & 33 & 15 & 6 \\
\hline
\end{tabular}

Because the two treatment groups differed at the onset of the trial, direct comparison of distribution as the trial progressed is not justifiable.

Resolution of Pain.-This is shown graphically in Fig. 1. The percentage of patients becoming pain-free increased from 6 to 52 in the oxyphenbutazone group (i.e. 46 per cent.) and from 19 to 65 in the prednisolone group (i.e. 46 per cent.) during the first 7 days. The advantage shown by the prednisolone group before treatment persisted up to Day 21, i.e. the groups improved in parallel, but by Day 28 the advantage was with the oxyphenbutazone group (5 per cent. more without pain) increasing to 13 per cent. by Day 42. These figures are shown in Table VII.

TABLE VII

Percentage of Pain-free Eyes

\begin{tabular}{c|r|r|r|r|r|r|l}
\hline \multirow{2}{*}{ Group } & \multicolumn{7}{|c}{ Day } \\
\cline { 2 - 8 } & 0 & 7 & 14 & 21 & 28 & 42 & 56 \\
\hline $\begin{array}{l}\text { Oxyphenbutazone } \\
\text { Prednisolone }\end{array}$ & 6 & 52 & 70 & 61 & 67 & 64 & 61 \\
\hline
\end{tabular}

This method of comparison deals only with the patients who were pain-free at each assessment. It does not take into account those who had a reduction in pain but were not pain-free.

Percentage of Eyes improving or becoming Worse.-This is shown graphically in Fig. 2 constructed from figures given in Table VIII (overleaf). 
TABLE VIII

Pain: Percentage of Eyes improving or Deteriorating

\begin{tabular}{ll|r|r|r|r|r|r}
\hline \multirow{2}{*}{ Group } & \multicolumn{7}{c}{ Day } \\
\cline { 3 - 8 } & 7 & 14 & 21 & 28 & 42 & 56 \\
\hline \multirow{2}{*}{ Upgraded } & $\left\{\begin{array}{l}\text { Oxyphenbutazone } \\
\text { Prednisolone }\end{array}\right.$ & 76 & 30 & 12 & 15 & 9 & 6 \\
\hline \multirow{2}{*}{ Downgraded } & 76 & 24 & 11 & 8 & 13 & 13 \\
\hline
\end{tabular}

At Day 7 there was no difference -76 per cent. of both groups had been upgraded, 5 per cent. downgraded, and 19 per cent. showed no change. At Day 14 a slightly higher proportion of the oxyphenbutazone group was upgraded, but also a slightly higher proportion downgraded. At Day 21 fewer were downgraded in the oxyphenbutazone group, but this was complicated by a higher percentage of withdrawals. At Days 28 and 42 the salient feature is the higher proportion of the prednisolone group which had been downgraded, but there was a partial recovery at Day 56.

Improvement in Pain.-It is obvious that a pain-free eye cannot improve in this respect, though it can deteriorate four grades to severe and constant pain. Similarly, an eye with constant severe pain cannot become more painful, though it could improve four grades to pain-free. A method was devised to differentiate, for example, between the eye which improved from "severe constant" pain to "mild intermittent" pain and the eye which improved from "mild intermittent" pain to no pain.

This was done by expressing the actual number of grades improved by each treatment group as percentages of the possible number of grades of improvement, as shown, for example, in the oxyphenbutazone group at Day 0:

2 eyes in category 0 could improve 0 categories each $=0$ 13 eyes in category 1 could improve 1 categories each $=13$ 11 eyes in category 2 could improve 2 categories each $=22$ 5 eyes in category 3 could improve 3 categories each $=15$ 2 eyes in category 4 could improve 4 categories each $=8$ )

Possible

Total 58

It was found that the actual number of grades which the eyes improved was 42 , or 72 per cent. of the possible number. Similar calculations were made for both treatment groups at each day of assessment. These were repeated for downgrading. The differences between the percentages in the two groups were tested for statistical significance.

The only significant difference was the excess of downgrading in the prednisolone group between Days 21 and 28. During this week the actual number of grades retrogressed was 13 per cent. of the possible number as against only 4 per cent. in the oxyphenbutazone group. The trend of the upgrading percentages is of interest, since it suggests that up to Day 21 the prednisolone group had the advantage, but 
subsequently the oxyphenbutazone group showed greater improvement, while after Day 21 the prednisolone group showed greater deterioration. These figures are illustrated graphically in Fig. 3 (a and b).

TABLE IX

Pain: Grades of Improvement and Deterioration as a Percentage of THE Possible Number of Grades OF IMPROVEMENT OR DETERIORATION

\begin{tabular}{|c|c|c|c|c|c|c|}
\hline \multirow{2}{*}{ Group } & \multicolumn{6}{|c|}{ Day } \\
\hline & 7 & 14 & 21 & 28 & 42 & 56 \\
\hline Upgrading $\left\{\begin{array}{l}\text { Oxyphenbutazone } \\
\text { Prednisolone }\end{array}\right.$ & $\begin{array}{l}72(58) \\
76(59)\end{array}$ & $\begin{array}{l}56(18) \\
85(16)\end{array}$ & $\begin{array}{l}31(13) \\
33(12)\end{array}$ & $\begin{array}{l}71(7) \\
50(16)\end{array}$ & $\begin{array}{ll}50 & (6) \\
41 & (7)\end{array}$ & $\begin{array}{l}43(7) \\
39(19)\end{array}$ \\
\hline Downgrading $\left\{\begin{array}{l}\text { Oxyphenbutazone } \\
\text { Prednisolone }\end{array}\right.$ & $\begin{array}{l}3(70) \\
2(89)\end{array}$ & $\begin{array}{l}4(114) \\
5(128)\end{array}$ & $\begin{array}{l}2(103) \\
6(134)\end{array}$ & $\begin{array}{r}4(101) \\
13(130)^{*}\end{array}$ & $\begin{array}{r}4(102) \\
10(115)\end{array}$ & $\begin{array}{l}4(101) \\
6(105)\end{array}$ \\
\hline
\end{tabular}

* = statistically significant at 0.05 level.

Figures in brackets show the number of possible grades.

Table IX shows the complete results for this index; the figures in parentheses are the possible grades of improvement (or deterioration) on which the percentages are based. They are of importance, since an improvement of 50 per cent. of thirty possible grades is of interest, whereas an improvement of 50 per cent. of two possible grades is meaningless.

\section{Improvement during the First 7 Days}

For the first period of the trial only (Day 0 to Day 7), the number of grades of improvement or deterioration was examined in still greater detail (Table X). This examination showed that it was possible for:

(a) 7 eyes in the $O$ group to improve 3 grades, and that 4 did so, i.e. 57 per cent. compared with 60 per cent. in the $P$ group.

(b) 18 eyes in the $\mathrm{O}$ group to improve 2 or more grades and that 13 did so, i.e. 72 per cent. compared with 61 per cent. in the $P$ group.

(c) 31 eyes in the $\mathrm{O}$ group to improve 1 grade or more and that 25 did so, i.e. 81 per cent. compared with 93 per cent. in the $\mathbf{P}$ group.

The last difference is significant.

TABLE X

Pain: Grades of Improvement or Deterioration during First Week of Trial

\begin{tabular}{l|c|c|c|c|c|c}
\hline \multirow{2}{*}{ Grades } & \multicolumn{2}{|c|}{$\begin{array}{c}\text { No of Eyes which } \\
\text { could improve } \\
\text { (a) }\end{array}$} & $\begin{array}{c}\text { No. of Eyes which } \\
\text { did improve during } \\
\text { first } \\
\text { (b) days }\end{array}$ & \multicolumn{2}{|c}{$\begin{array}{c}\text { (b) } \\
\text { as a percentage } \\
\text { of } \\
\text { (a) }\end{array}$} \\
\cline { 2 - 7 } & $\mathbf{O}$ & $\mathbf{P}$ & $\mathbf{O}$ & $\mathbf{P}$ & $\mathbf{O}$ & $\mathbf{P}$ \\
\hline Three & 7 & 5 & 4 & 3 & 57 & 60 \\
\hline Two or more & 18 & 23 & 13 & 14 & 72 & 61 \\
\hline One or more & 31 & 30 & 25 & 28 & 81 & 93 \\
\hline
\end{tabular}


Flare, Keratic Precipitates, and Cells.-These were present on too few occasions for valid statistical conclusions to be drawn.

\section{Episcleral Injection}

Resolution of Episcleral Injection.-At each assessment (original and follow-up) the number of eyes with $0,1,2,3$, or 4 quadrants affected was recorded as a percentage. In the oxyphenbutazone group the number of eyes with no quadrants affected steadily increased from nil on Day 0 to 70 per cent. at Day 56, whereas the prednisolone group showed a more rapid improvement from 11 per cent. at Day 0 to 65 per cent. at Day 21 and then relapsed to 43 per cent. by Day 56 . These results are shown in Table XI and illustrated graphically in Fig. 4.

TABLE XI

Percentage of Eyes with no Episcleral InJection

\begin{tabular}{c|r|c|c|c|c|c|c}
\hline \multirow{2}{*}{ Group } & \multicolumn{7}{c}{ Day } \\
\cline { 2 - 8 } & 0 & 7 & 14 & 21 & 28 & 42 & 56 \\
\hline $\begin{array}{l}\text { Oxyphenbutazone } \\
\text { Prednisolone }\end{array}$ & 0 & 18 & 39 & 33 & 48 & 52 & 70 \\
\hline
\end{tabular}

Improvement in Episcleral Injection.-The actual amount of upgrading expressed as a percentage of that possible is shown graphically in Fig. 5. There was more improvement in the prednisolone group up to Day 21 (47 per cent. in the prednisolone group, 31 per cent. in the oxyphenbutazone group), but after Day 21 there was more upgrading in the oxyphenbutazone group and more downgrading in the prednisolone group. The differences in favour of oxyphenbutazone were significant at Day 56 for upgrading and at Day 28 for downgrading. Detailed figures are shown in Table XII.

TABLE XII

Episcleral InJection: Grades of Improvement and Deterioration as a Percentage of the Possible Number of Grades of IMPROVEMENT OR Deterioration

\begin{tabular}{|c|c|c|c|c|c|c|}
\hline \multirow{3}{*}{ Group } & \multicolumn{6}{|c|}{ Day } \\
\hline & 7 & 14 & 21 & 28 & +42 & 56 \\
\hline & Per cent. & Per cent. & Per cent. & Per cent. & Per cent. & Per cent. \\
\hline Upgrading $\left\{\begin{array}{l}\text { Oxyphenbutazone } \\
\text { Prednisolone }\end{array}\right.$ & $\begin{array}{l}38(60) \\
47(66)\end{array}$ & $\begin{array}{l}36(39) \\
38(37)\end{array}$ & $\begin{array}{l}31(26) \\
47(30)\end{array}$ & $\begin{array}{l}32(25) \\
30(20)\end{array}$ & $\begin{array}{l}50(14) \\
21(24)\end{array}$ & $\begin{array}{l}43(14) \\
12(33)^{*}\end{array}$ \\
\hline Downgrading $\left\{\begin{array}{l}\text { Oxyphenbutazone } \\
\text { Prednisolone }\end{array}\right.$ & $\begin{array}{l}3(73) \\
4(82)\end{array}$ & $\begin{array}{l}1 \text { (93) } \\
7 \text { (107) }\end{array}$ & $\begin{array}{l}8(92) \\
4(114)\end{array}$ & $\begin{array}{c}0(93) \\
14(124) *\end{array}$ & $\begin{aligned} 7(94) \\
15(104)\end{aligned}$ & $\begin{array}{l}1(94) \\
5(91)\end{array}$ \\
\hline
\end{tabular}

* = statistically significant at 0.05 level

Figures in brackets are the number of possible grades. 
Both groups improved comparably up to Day 21 , but after this the oxyphenbutazone group continued to improve while the prednisolone group deteriorated, and these differences are statistically significant.

\section{Conjunctival Injection}

Resolution of Conjunctival Injection.-This is shown graphically in Fig. 6, prepared from the figures in Table XIII.

TABLE XIII

Percentage of Eyes with no Conjunctival InJection

\begin{tabular}{c|r|r|r|r|r|r|c}
\hline \multirow{2}{*}{ Group } & \multicolumn{7}{c}{ Day } \\
\cline { 2 - 8 } & 0 & 7 & 14 & 21 & 28 & 42 & 56 \\
\hline $\begin{array}{l}\text { Oxyphenbutazone } \\
\text { Prednisolone }\end{array}$ & 3 & 24 & 33 & 30 & 39 & 45 & 54 \\
\hline
\end{tabular}

On entry to the trial the prednisolone group was less severely affected, 11 per cent. having conjunctival injection, but by Day 7 both had the same proportion (76 per cent,) affected. From Day 7 to Day 28 the prednisolone group improved more quickly than the oxyphenbutazone group, but on Days 42 and 56, the percentage with no quadrant affected was the same in the two groups.

Improvement in Conjunctival Injection.-When this criterion was examined in more detail (Fig. 7 (a and b) and Table XIV) and the total amount of upgrading measured as a percentage of possible upgrading, the prednisolone group was better up to Day 21, significantly so at Day 21 , but after Day 28 the oxyphenbutazone group did better. Similarly, by Days 28 and 42, the prednisolone group had deteriorated significantly as compared with the oxyphenbutazone group.

TABLE XIV

Conjunctival InJection: Grades of IMProvement and Deterioration as a Percentage of the Possible Number of Grades of Improvement or Deterioration

\begin{tabular}{l|c|c|c|c|c|c}
\hline \multirow{2}{*}{ Group } & \multicolumn{7}{|c}{ Day } \\
\cline { 2 - 8 } & 7 & 14 & 21 & 28 & 42 & 56 \\
\cline { 2 - 8 } & Per cent. & Per cent. & Per cent. & Per cent. & Per cent. & Per cent. \\
\hline Upgrading $\left\{\begin{array}{l}\text { Oxyphenbutazone } \\
\text { Prednisolone }\end{array}\right.$ & $42(65)$ & $28(40)$ & $19(31)$ & $24(29)$ & $45(20)$ & $25(16)$ \\
\hline Downgrading $\left\{\begin{array}{l}\text { Oxyphenbutazone } \\
\text { Prednisolone }\end{array}\right.$ & $3(69)$ & $42(38)$ & $52(29)^{*}$ & $30(20)$ & $36(25)$ & $18(33)$ \\
\hline
\end{tabular}

* = statistically significant at 0.05 level.

Figures in brackets are the number of possible grades.

Thus one may conclude that as regards conjunctival injection the prednisolone group was significantly better up to Day 21 , but the group showed significant deterioration during and after withdrawal of treatment. 


\section{Improvement during the First 7 Days}

Examination shows that of the eyes which could improve two or more grades in the first 7 days, 19 per cent. of the oxyphenbutazone group and 35 per cent. of the prednisolone group did so. This difference is not significant.

However, of those which could improve one or more grades, 50 per cent. of the oxyphenbutazone group did so, as against 75 per cent. of the prednisolone group

$$
\left(\frac{\text { Diff. }}{\text { S.E. }}=\frac{25 \text { per cent. }}{12 \cdot 1)}\right)
$$

This is significant and confirms the advantage to the prednisolone group in this early period of the trial.

\section{Nodule Scores (Fig. 4)}

As mentioned earlier each nodule scored 1 if just definite, 2 if fairly obvious, 6 if very obvious, and 10 if large and confluent with neighbouring nodules. It was thus possible to calculate mean scores for each treatment group at every assessment. These means are shown in Table XV, and Fig. 8 shows these means as a percentage of the mean score at Day 0 .

TABLE XV

“MEAN" SCORES

\begin{tabular}{|c|c|c|c|c|c|c|}
\hline \multirow{2}{*}{ Day } & \multicolumn{2}{|c|}{ Nodules } & \multicolumn{2}{|c|}{$\begin{array}{l}\text { All Symptoms* and } \\
\text { Signs except Nodules }\end{array}$} & \multicolumn{2}{|c|}{$\begin{array}{l}\text { All Symptoms* and } \\
\text { Signs including Nodules }\end{array}$} \\
\hline & $\begin{array}{l}\text { Oxyphen- } \\
\text { butazone }\end{array}$ & Prednisolone & $\begin{array}{l}\text { Oxyphen- } \\
\text { butazone }\end{array}$ & Prednisolone & $\begin{array}{l}\text { Oxyphen- } \\
\text { butazone }\end{array}$ & Prednisolone \\
\hline $\begin{array}{r}0 \\
7 \\
14 \\
21 \\
28 \\
42 \\
56\end{array}$ & $\begin{array}{ll}3 \cdot 52 & (33) \\
1.94 & (33) \\
0 \cdot 82 & (33) \\
0 \cdot 86 & (29) \\
0 \cdot 45(29) \\
0 & (27) \dagger \\
0 & (27)\end{array}$ & $\begin{array}{l}3.24(37) \\
0.78(37) \\
0.27(36) \\
0.25(36) \\
0.17(36) \\
0.69(32) \\
0.39(31)\end{array}$ & $\begin{array}{l}6 \cdot 27 \\
3 \cdot 27 \\
2 \cdot 58 \\
2 \cdot 72 \\
2 \cdot 07 \\
1 \cdot 63 \\
1 \cdot 30\end{array}$ & $\begin{array}{l}6 \cdot 11 \\
2 \cdot 95 \\
2 \cdot 33 \\
1 \cdot 86 \\
2 \cdot 94 \\
3 \cdot 50 \dagger \\
3 \cdot 32 \dagger\end{array}$ & $\begin{array}{l}9 \cdot 79 \\
5 \cdot 21 \\
3 \cdot 39 \\
3 \cdot 59 \\
2 \cdot 52 \\
1 \cdot 63 \dagger \\
1 \cdot 30 \dagger\end{array}$ & $\begin{array}{l}9 \cdot 35 \\
3 \cdot 73 \\
2 \cdot 81 \\
2 \cdot 11 \\
3 \cdot 11 \\
4 \cdot 19 \\
3 \cdot 71\end{array}$ \\
\hline
\end{tabular}

* This excludes categories of scleral thinning and degree of keratitis because a change from one grade to another does not necessarily mean improvement or deterioration.

$\dagger=$ statistically significant at 0.05 level.

The mean nodule score of the oxyphenbutazone group was higher (but not significantly so) up to Day 28 . Subsequently the score in this group was nil while that of the prednisolone group increased, so that on Day 42 the mean of the prednisolone group was significantly higher, and remained higher at Day 56. The mean score of the prednisolone group fell more rapidly than the oxyphenbutazone group until Day 28 and then rose. This conforms with the pattern of the other symptoms and signs.

Since patients who scored nil for nodules at the start of the trial could not improve, the means were recalculated when such patients were excluded. The deductions made were entirely unchanged, the significant advantage to the oxyphenbutazone group at Day 42 persisted, and the trend of the means remained similar for both groups. 
By transforming the nodule scores of $0,1,2,6$, and 10 into categories $1,2,3,4$, and 5 , the proportions of eyes which improved or deteriorated one, two, and three categories during the first 7 days of the trial were compared in the two groups. No eye in either group improved more than three categories, but 5 out of 17 possible ( 29 per cent.) in the prednisolone group improved three categories as against 1 out of 13 possible in the oxyphenbutazone group ( 8 per cent.). The difference ( 21 per cent.) is not significant, but taken in conjunction with those which improved two categories-73 per cent. in the prednisolone group against 30 per cent. in the oxyphenbutazone group, and also with those which improved one category ( 88 per cent. prednisolone against 68 per cent. oxyphenbutazone) - the advantage to the prednisolone group in this early stage of the trial is manifest.

\section{Combined Score for Symptoms and Signs except Nodules (Fig. 9)}

While it is realized that there may be statistical objections, all the signs and symptoms which were given a numerical code were added together and the means were calculated (scleral thinning and quality of keratitis were not included; scleral thinning being the end-point of the inflammatory process, and a change of grade of keratitis not necessarily showing an improvement or deterioration). These means are shown in Table XV.

The two groups had similar means, declining in value to Day 21, the oxyphenbutazone group being slightly higher throughout, but at Day 28 the prednisolone group mean had increased and increased still further by Day 42, so that the mean score for the prednisolone group was significantly higher on Days 42 and 56.

The trends of the means (taking Day 0 as 100), are somewhat different from those for nodules and are shown graphically in Fig. 9. The dramatic fall in the nodule score for the prednisolone group at Day 7 was not apparent as regards the score for the other symptoms. At Day 7 the mean score of both treatment groups was approximately 50 per cent. of that at Day 0 , and subsequent decline was more gradual than for nodule scores. While the mean of the oxyphenbutazone group was only 21 per cent. of the initial mean score at Day 56, the prednisolone group attained a minimum of 30 per cent. at Day 21 and then retrogressed to 54 per cent. at Day 56. These differences in favour of oxyphenbutazone are significant at Days 42 and 56.

\section{Total Scores for Nodules, Symptoms, and Signs}

When the scores for nodules and all other signs were combined to give an overall picture (Fig. 10), the pattern was again repeated, the oxyphenbutazone group showing a steady improvement throughout the trial period, attaining 53 per cent. of the initial score at Day 7 and then falling to 13 per cent. at Day 56 . The prednisolone group, on the other hand, showed a more rapid improvement (to 40 per cent. of initial score at Day 7), and continued to improve to Day 21 (23 per cent. of initial score), but then relapsed quite markedly, and by Day 42 still showed 45 per cent. of initial score. The actual means are shown in Table XV.

Thus, the pattern of these "mean scores" for all symptoms combined conforms generally to that of the more valid mean scores for nodules. 